\title{
nature
}

\section{Wanteds a free rein for Germany's universities}

Against a background of progressive change in the running of Germany's research, the universities stand out as bastions of down-at-heel conservatism. Increased competition is the way forward.

A $\mathrm{t}$ the start of this decade, prospects for German science were looking bleak. A variety of factors conspired to keep German laboratories closed to new and important research areas, particularly genetics and informatics, and to keep young blood yoked until middle age within overly rigid disciplinary boundaries and outdated systems of employment.

But in the past few years the landscape has begun to be transformed, thanks not least to a new generation of strong leaders in key positions. Former research minister Jürgen Rüttgers was the first to take a decisive stand. He relaxed Germany's notoriously bureaucratic laws regulating research in genetic manipulation, and in 1996 launched an astonishingly successful regional biotechnology competition, BioRegio, which cunningly forced the Länder (states) to face up to new economic opportunities. He created well-funded programmes for genome research and information sciences. Biotechnology companies sprang up in what had been a desert.

Hard on Rüttgers' heels came Hubert Markl and Ernst-Ludwig Winnacker, respective heads of the Max Planck Society and the Deutsche Forschungsgemeinschaft, the university granting agency, with a series of bold and important reforms; to name a few: the promotion of the academic careers of young scientists and women, the creation of graduate colleges to be run by universities and Max Planck institutes, and the concentration of money in strategic areas of basic research identified by the scientific community itself.

The universities have proven the last bastion against change. But now it seems that even they are starting to shift. The moves by the University Rectors' Conference (HRK) to recommend the creation of a type of short-term assistant professorship, and to push for performance-related pay, are significant (see page 299). In the new reformoriented climate, no one doubts that the necessary changes to federal law will be carried through. But equally important is investment in university infrastructure. Germany adheres with pride to the Humboldt principle of teaching in an environment of research, but whereas a Max Planck institute typically boasts world-class facilities, a neighbouring university laboratory is likely to look shabby by comparison.

The Max Planck Society is a strong umbrella organization; the universities, proudly independent, are weakened as a lobby group because of their individual isolation; that partly explains the decline in their funds. Moreover, independence is a relative term. Universities are financed by the Länder governments, and so are free from federal interference. But most universities have only recently been given the right to administer their own budgets (though few have as yet rushed to exploit the advantages). And only last year were they allowed to select a small proportion — 20 per cent — of their students.

To supplement the new reforms, universities must become much more independent. They must grasp the opportunities to establish competition for resources between faculties and research groups. But competition must also be introduced at the federal level. The law blocking universities from selecting their own students, built on the laudable but fiscally insupportable concept that all those with a highschool Arbitur should have the right to a university education, must be changed. Universities cannot go on sagging under the resourcedraining weight of thousands of students they do not want to teach, a high proportion of whom will not complete their degree.

In under-subscribed but important courses like chemistry and physics, universities should be able to fight for the best. And the best students will want to attend a strong research university with a good teaching record. Länder governments will then need to worry about losing out to their neighbours and rivals, and be more ready to provide the necessary levels of core funding for their universities.

\section{Farewell to a friend}

\section{George Brown was science's best friend in Congress because he saw it as the only foundation for a just society.}

In an age of growing public cynicism about politics, the United States Congress can ill afford to lose the likes of George Brown (Democrat, California), the senior minority member of the Science Committee of the House of Representatives, who died last week after serving in the Congress for 36 years.

Science in the United States is indebted to Brown not just for his support of scientific programmes - which was unwavering, if never uncritical - but also for his desire to ensure that scientific issues were aired with an eloquence and sophistication rarely found elsewhere on Capitol Hill.

Even as chair of the Science Committee, before 1995, Brown had limited influence in Washington. Like its approximate counterparts in many other countries, the Science Committee is a minor player in the Congress's power structure. As a lifelong liberal and pacifist, whose seniority had been curtailed when he stepped out of the House to unsuccessfully run for a California Senate seat in 1970, Brown had no illusions about his own place within that structure.

But he showed that, even if its budgetary influence was small, it was possible for the committee to serve as an effective forum for scientific ideas. With the aid of a strong specialist staff (rather than the usual collection of political hangers-on), Brown managed to nurture a discussion of scientific subjects in the US Congress that transcended 'pork barrel' politics and helped to create an environment in which science could better support good government.

Brown's motive for this endeavour was never doubted, and was indeed invoked last Friday in a moving tribute from his friend and rival, Jim Sensenbrenner (Republican, Wisconsin), the current chair of the Science Committee. Quite simply, Brown believed that science could form the basis of a more just and peaceful world. Researchers can pay tribute to his memory by keeping that noble aim in mind. 